\title{
Servant Leadership: Son of Man as Minister and Life Giver in Mark 10.45
}

\author{
Mookgo Solomon Kgatle \\ University of Pretoria, 0002 South Africa \\ kgatles@yahoo.com
}

\begin{abstract}
This article discusses the Son of Man as Minister and Life giver in Mk 10.45. The Son of Man as Minister is the servant who did not come on earth to be ministered to but to minister to others. The Son of Man as the Life giver is the servant who pays a price for the sake of many sinners in the world. The life, crucifixion, death, and resurrection of the Son of Man become that price for the release of those who are enslaved by sin. The purpose of this article is to demonstrate that these aspects of the Son of Man Minister and Life giver - are aspects of servant leadership.
\end{abstract}

Keywords: servant leadership - Son of Man - minister - life giver - ransom

\section{Introduction}

Servant leadership is a style of leadership that is different from the decision making models (autocratic, democratic, consultative, and team directed) and path goal models (directive, supportive, participative, and achievementoriented). It is different from other styles of leadership like transformational, transactional, charismatic, and situational. Servant leadership is a model that

* Mookgo Solomon Kgatle (PhD, University of Pretoria) is a research associate of the Department of New Testament Studies, University of Pretoria, 0002, South Africa. This article flows from his PhD thesis titled Servant leadership in Mark 10:35-45 applied to African Pentecostal Christianity, completed under the supervision of Prof. Dr Ernest van Eck. 
is based on service. 'Servant leadership' was coined and developed as a model by R.K. Greenleaf (1904-1990) in the late seventies. Since then, many other servant leadership scholars have come on board in support of this study, theory, and philosophy based on service. ${ }^{1}$

These scholars, like Greenleaf, applied servant leadership in corporate business. It is clear that the basis of their philosophy and teaching was not a biblical one. Hutchison acknowledges the fact that 'many books have been written on the subject of leadership by Christian and secular leaders in corporate business.' ${ }^{2}$ Few topics have created as much discussion and debate in both contexts as the concept of servant leadership. Since Jesus and essentially every New Testament writer inextricably associated Christian leaders with servanthood, one would expect to find this subject discussed in Christian literature.

Hutchison continues to say that 'Greenleaf never claimed that his book is religious in nature. Yet he presented a new paradigm for business managers, one that has gained followers in the past thirty years.' ${ }^{3}$ With the exception of Gene Wilkes' Jesus on Leadership ${ }^{4}$ the subject of servant leadership has not been approached from a biblical perspective, a greater work can still be done in this regard. The purpose of this article is to make a contribution to a growing scholarly research in servant leadership. Furthermore, it is to bridge the gap on the study of servant leadership from a biblical perspective.

\section{Mark 10.45}

'For even the Son of Man came not to be ministered unto, but to minister, and to give his life a ransom for many' (Mk 10:45).

Various New Testament scholars have made their contribution to the context of Mk 10.45. In this text, Johnson says that 'Jesus' illustration on humble

1 In 1998, Batten, Bauch, Blanchard, Bottum, Graham, Lenz, Melrose, Schuster, contributed to Insights on Leadership. In 2002, Beazley, Beggs, Bennis, Depree, Covey, Farnsworth, Jones, McGee-Cooper, Moxley, Ruschman, Smith, Spears, Trammell, Williams, and Young all contributed to Focus on Leadership: Servant Leadership for the $21^{\text {st }}$ Century. In 2004 Burkhardt, DeGraaf, Ferch, Frick, Neal, Spears, and Tilley made a contribution to practising servant leadership. In 2006, Flaniken asked an important question: is the Bible relevant to servant leadership? In 2010, Bekker, Dierendonck, and Patterson contributed to Servant Leadership: Developments in Theory and Research.

2 John C. Hutchison, 'Servant-Hood: Jesus' Countercultural call to Christian Leaders', Bibliotheca Sacra 166.1 (2009), pp. 53-69.

3 Hutchison, 'Servant-Hood', p. 53.

4 C.G. Wilkes, Jesus on Leadership (Wheaton, IL: Tyndale House, 1998). 
service is better expressed, and it is characteristic of Mark that the pattern is the Son of Man. He is not just an apocalyptic judge but the one who has healed the sick, embraced children and patiently taught His disciples'. ${ }^{5}$ The text, according to Williamson, affirms that 'Jesus' life was one of service and that His death was for others. His life and death were of peace, for the supreme service of Jesus Christ was the voluntary giving of His life as a ransom for many' ${ }^{6}$

Mark's picture of Jesus holds in tension two ideas, lordship and service. Seeley asserts that the "two stand in sharp contrast to one another. Indeed, it is precisely the tension between them that gives this text much of its force. Unlike those who are regarded as ruling over nations, Jesus is a minister and life giver.' ${ }^{7}$ According to Geisler 'Jesus illustrates His humility and in service to His disciples'. ${ }^{8}$ Furthermore, Hutchison states that 'Jesus challenged His disciples to a radical and paradoxical form of leadership and showed that He Himself would provide the ultimate example through His suffering and death'. ${ }^{9}$

In addition, His death is not only the supreme example of what it means to be 'Great' in the kingdom of God, that is, being a servant and slave of all. According to Stein, 'it is also the once-for-all sacrifice by which He vicariously ransomed humanity from sin and death. ${ }^{10}$ In the words of Burge and Hill, 'the text attests to Jesus' supreme consciousness of His impending suffering and death in Jerusalem as a 'ransom for many', as self-substitution on behalf of all humanity.'11

Therefore Mk 10.45 is about the Son of Man as Minister and Life giver. The purpose of this article is to demonstrate that the aspects of the Son of Man in Mk 10.45, that is, Minister and Life giver, are aspects of a servant leadership. This will be achieved by studying each aspect independently and make a conclusion that all aspects relate to the aspects of servant leadership.

5 Sherman E. Johnson, The Gospel According to Saint Mark (New York: Adam \& Charles Black, 2nd edn, 1972), p. 178.

6 L.R. Williamson, Mark (Interpretation: A Bible Commentary for Teaching and Preaching; Atlanta: John Knox, 1983), p. 190.

7 David Seeley, 'Rulership and Service in Mk 10.41-45', Novum Testamentum 35.3 (1993), pp. 234-50.

8 Norman L. Geisler, A Popular Survey of the New Testament (Grand Rapids, M I: Baker Books, 2007), p. 73 .

$9 \quad$ Hutchison, 'Servant-Hood', p. 54.

10 Robert H. Stein, Mark (Louisville, KY:, 2008), p. 489.

11 Garry M. Burge \& Andrew E. Hill, The Baker illustrated Bible Commentary (Grand Rapids, MI: Baker, 2012), p. 1036. 


\section{Aspects of the Son of Man in Mark 10.45}

\subsection{Minister}

'For even the Son of Man came not to be ministered unto, but to minister' (Mk 10.45a). ${ }^{12}$

Mark reveals Jesus' character through six stages of the gospel, each stage building on the preceding one. Johnson says that 'the reader is progressively led to recognise Jesus' attributes as a healer, a rejected prophet, a servant who undergoes public humiliation, death, a rising, returning Son of Man'. ${ }^{13}$ However, of all the six attributes the servant imagery frames the whole of Jesus' story throughout the gospel and the centre of the story is the passion account. Broadhead points out that 'the servant imagery is thus a passion metaphor which moves out from the scenes of Jesus' death to encompass the whole story and it provides a distinct pattern for the characterisation and Christology in the gospel of Mark'.14

According to Alexander 'the Son of Man, the Messiah in His humiliation, did not come into the world to be ministered unto, waited upon or personally to be served by others, but to minister, serve or wait on others'. ${ }^{15}$ Hay says that 'the Son of Man means to be both the object and the agent of the divine purpose of serving others. ${ }^{16}$ Morgan maintains that 'Jesus came not to be ministered to, not to compel men to gather about Him, to serve Him, and lift Him, and honour Him; not to secure His own immunity from suffering or sorrow, or to make sure of His own joy and His own pleasure.' ${ }^{17}$ He came 'to serve' according to Brown refers to 'the way Jesus is ready to serve humanity'. ${ }^{18}$ Jesus was like a slave in that He stripped Himself of all rights and security. Macleod is of the opinion that 'Jesus was like a slave because He did not seek honor and glory but to serve the people of God'. ${ }^{19}$ Jesus became human for humanity's sake. Jesus became a servant to set humanity free. Salvation is possible only because Jesus

\footnotetext{
12 This Scripture and other subsequent Scriptures are taken from the King James Version.

13 Johnson, The Gospel According to Saint Mark, p. 82.

14 Edwin K. Broadhead, Naming Jesus: Titular Christology in the Gospel of Mark (Sheffield: Sheffield Academic Press, 1999), p. 107.

15 Joseph A. Alexander, The Gospel according to Mark (London: Banner of Trust 1961), p. 293.

16 Lewis S. Hay, 'The Son of God Christology in Mark', Journal of Bible and Religion 32.2 (1964), pp. 106-14.

17 G. Campell Morgan, The Gospel according to Mark (London: Revell Company, 1985), p. 243.

18 Rick Brown, 'The son of God: Understanding the Messianic Titles of Jesus' JFM 17.1 (2000), pp. $41-52$.

19 David J. Macleod, 'Imitating the Incarnation of Christ: An exposition of Philippians 2:5-8', Bibliotheca Sacra 158.63 (2001), pp. 308-30.
} 
became human. Matz emphasises the fact that 'Jesus' humanity moulds and shapes humanity. His humanity makes Him approachable to men. He went through a time of suffering in order that humanity is able to overcome the suffering of sinful desires'. ${ }^{20}$ According to Douglass and Tenney, 'Son of Man does not refer to the humanity of Jesus but to His willingness to die for humanity'. ${ }^{21}$ Son of $\mathrm{Man}^{22}$ as a Minister means that Jesus was willing to serve man in His life, crucifixion, death, resurrection and ascension. Son of Man does not refer to Jesus born by Joseph and Mary as opposed to Son of God as born by His father in heaven. It refers to Jesus' willingness to die for humanity. Jesus in Mark is suffering servant. In addition, His message in the gospel is contextualised around serving other people. Jesus does not only teach about service, He is prepared to model the concept. He is willing to die the death of the cross in order to liberate men from their sins and from the power of death.

This was true in the whole course of His public life, most emphatically true of the great sacrifice He made that was to end His life. Although it was the great end of His mission and His incarnation, yet He did not boast about it. The reversal of all human ideas of greatness and rank was achieved when Jesus came not to be served, but to serve. He voluntarily veiled His glory as the Son of $\operatorname{Man}(\operatorname{Mk} 8.38 ; 13.26 ; 14.62)$ and assumed the form of a slave who performed His service unto death because this was the will of God (Phil. 2.6-8). In Mk 10.45, the death of Jesus is presented as His service to God and as a vicarious death for the remission of sins.

The formulation 'the Son of Man came', places the entire statement in the context of Jesus' messianic mission (Mk 2.17). The service in which the royal will of the Son of Man is displayed and fulfilled in His giving of Himself. In a Jewish frame of reference this expression was characteristically used for the

$20 \quad$ Brian Matz, 'Philippians 2:7 as Pastoral Example in Gregory Nazianzen's Oration 12', Greek Orthodox Theological Review 49 (3-4), pp. 279-90.

21 J.D. Douglas, \& M.C. Tenney, Zondervan Illustrated Bible Dictionary (Grand Rapids: Zondervan, 2011), p. 286.

22 The most important dimension of Jesus in Mark Jesus is the Son of Man, the Messiah, the one that had to suffer and die in obedience to God. The Son of Man is not a divine miracle worker, but the one that is rejected, scorned, flogged and killed. It emphasises Jesus' suffering and death as well as His future exaltation. The theme of suffering linked not only to Jesus, the suffering Christ and Son of God as Son of Man, but also to the disciples and the suffering followers of Jesus is presented in Mark. See Ernest Van Eck, Introduction to the New Testament: The Synoptic Problem and Introduction to and Exegesis and Theology of Mark (University of Pretoria: Faculty of Theology-Department of New Testament Studies, Pretoria, 2013), pp. 71-74. 
death of martyrs. ${ }^{23}$ In this context it expresses the element of voluntariness or self-sacrifice in the death of Jesus who offers Himself in obedience to the will of God. His death has infinite value because He dies not as a mere martyr but as the transcendent Son of Man.

\subsection{Life Giver}

' $[\mathrm{A}]$ nd to give his life a ransom ${ }^{24}$ for many' (Mk 10.45b).

Alexander says that 'ransom was the purchase which the Son of Man had come to make by the payment of Himself, His very soul or life, as a satisfaction to the divine justice. ${ }^{25}$ According to France 'it was traditionally used to refer to God's redemption of His people, not only from slavery in Egypt, but also from spiritual oppression and for payment to preserve a life which is legally forfeit or subject to divine punishment'. ${ }^{26}$ The act of setting a person free in this way was called 'redemption'. The person accomplishing the liberation was called a 'redeemer'. Jesus becomes the ultimate price of redemption of the release of humanity from bondage of sin.

Bracher and Nida states that 'To give His life' cannot be rendered literally. The meaning here is 'to die', but the implication is that He surrenders himself to death rather than being forced by others. Jesus has voluntarily given His life to humanity because no man can take it away from Him. The implication in the text means that by His payment many were released. ${ }^{27}$ Cole clarifies that 'his ransom price metaphor was one greatly beloved by the early church. It remains a strong statement of the purpose and efficacy of the atonement, and of its cost to God. ${ }^{28}$

231 Maccabees 2.50; 6.44.

24 Ransom is a sum of money or other payment demanded or paid for the release of a prisoner. It is the freedom of a prisoner through a payment. Ransom refers to that which one is set free, and particularly, the price paid to redeem (buy back again) a slave or captive out of bondage. Ransom is a demand concession from a person or organisation by threatening damaging action. 'To give His life a ransom for many' means He paid a certain price for the release of humanity from the bondage of sin and death. Jesus becomes the ultimate price paid to redeem humanity out of bondage. The price in this context is His life.

25 Alexander, The Gospel According to Saint Mark, p. 294.

26 Richard Thomas France, The Gospel of Mark: Commentary on the Greek Text (Grand Rapids, MI: Eerdmans, 2002), p. 420.

27 Robert G. Bratcher \& Eugene Albert Nida, The Gospel of Mark (UBs Handbook series; New York: UBS, 1961), p. $33^{2}$.

28 Alan Cole, The Gospel According to St Mark: An Introduction and Commentary (London: Tyndale House, 1961), p. 171. 
William alludes to the fact that 'the ransom metaphor sums up the purpose for which Jesus gave His life and defines the complete expression of His service. The prevailing notion behind the metaphor is that of deliverance by purchase, whether a prisoner of war, a slave, or a forfeited life is the object to be delivered'. ${ }^{29}$ Burn says that the statement 'Christ's life the ransom for many' has at least five implied meanings: First, life is forfeit. Second, sin so great an evil that even God cannot, without sacrifice, free people from it. Third, freedom without penalty would make people indifferent to doing wrong. Fourth, in love to man God punishes sin. Last, Christ shares that punishment to save people. ${ }^{30}$

According to Sanner 'the Son of Man came to give His life as a redemptive price for the freedom of slaves. ${ }^{31}$ Best says that 'Jesus' love in His death and its uniqueness has a redemptive significance. ${ }^{32}$ Williamson points out that 'Jesus has regained the life that humanity has lost. Jesus in His death and resurrection has saved humanity'. ${ }^{33}$ Furthermore Bratcher and Nida says that 'To give His life' means that Jesus died voluntarily. ${ }^{34}$ Senior remarks that 'the Son of Man's giving of life in ransom for the many is an act of service that contrasts sharply with the exploitive use of power and authority that characterises the "great ones" of the Gentiles who "lord it over" those they rule'. ${ }^{35}$ Carson states that the word 'Many' stresses rather the great number of those ransomed by His death. ${ }^{36}$

Jesus gave His life as a ransom for many means that Jesus as a servant leader pays the price for the liberation of people who are the slaves of sin, sickness, and oppression. He is the only one man who sacrifices His life for the liberty of many people. Jesus has already paid the price for the remission of sins. Therefore, humanity does not have to pay any other price for their redemption. Jesus as a servant leader does not come to humanity to take from them but $\mathrm{He}$ is a gift to humanity and the whole world. Jesus is the only sacrifice given for the lives of many people in the world.

29 L.L. William, The Gospel according to Mark (Grand Rapids MI: Eerdmans, 1974), p. 383.

$30 \quad$ J.H Burn, The Preacher's Complete Homiletic Commentary on the Gospel according St Mark (Grand Rapids, MI: Baker Books, 1974), p. 387.

31 A.E. Sanner, The Gospel According to Mark (Kansas City: Beacon Hill, 1979), p. 362.

32 Ernest Best, 'Mark's use of the Twelve' Zeitschrift für die neutestamentliche Wissenschaft und die Kunde der älteren Kirche 69.1-2 (1978), pp. 11-35.

33 Williamson, Mark, p. 190.

34 Bratcher \& Nida, The Gospel of Mark, p. 140.

35 Donald Senior, The Passion of Jesus in the Gospel of Mark (Wilmington, Delaware: Michael Glazier, 1984), p. 33.

36 D.A Carson et al., New Bible Commentary: $21^{\text {st }}$ Century Edition (Leicester: Intervarsity press, 1994), p. 967 . 


\section{Aspects of Servant Leadership}

\subsection{Servant Leadership is Service}

The Minister in Mk 10.45 is the one who serves others. Serving the needs of others is at the centre of servant leadership. To be a servant means to look for others' needs and try to meet them. ${ }^{37}$ The golden rule according to Manz is 'do to others as you would want them to do to you'.38 Servant leadership, according to Beazley and Beggs, 'begins with the concept of serving first and out of the desire to serve, that is, seeking to lead through the judicious and appropriate use of power. The goal or idea is to improve followers by increasing their autonomy, health, wisdom and freedom, thereby ensuring that the least privileged in society will either benefit or will not be further deprived'. ${ }^{39}$ Lore points out that 'follower should feel positively influenced rather than being controlled'. ${ }^{40}$

A servant leader in the words of Covey does not simply serve, but 'makes followers independent and capable and desirous of serving other people.41 Zohar states that 'servant leader becomes a model by serving other people'.42

37 Service to the followers is prioritised in contrast to personal agenda and power. Becoming a servant leader begins with the natural feeling that one wants to serve. This conscious choice then aspires one to leadership. A servant leader is sharply different from the one who is leader first, perhaps because with a need to assuage an unusual power-drive or to acquire material possessions. see R.K. Greenleaf, Servant Leadership: A Journey into the Nature of Legitimate Power and Greatness (New York: Paulist Press, 1997); R.K. Greenleaf, 'Servant leadership', in L.C. Spears (ed.), Insights on leadership (New York: John Wiley \& Sons, 1998), pp. 15-20; R.K. Greenleaf, 'Essentials of Servant-Leadership', in L.C. Spears \& M. Lawrence (eds.), Focus on Leadership: Servant-leadership for the $27^{\text {st }}$ Century (New York: Paulist Press, 2002), pp. 19-26; R.K. Greenleaf, 'Who is the servant-leader?' L.C Spears \& M. Lawrence (eds.), Practising Servant-Leadership (New York: John Wiley \& Sons, 2004), pp. 108.

38 Charles C. Manz, The Leadership Wisdom of Jesus: Practical Lessons for Today (San Francisco: Berrett-Koehler, 1999), p. 120.

39 H. Beazley \& J. Beggs, 'Teaching servant-leadership', in L.C. Spears, \& M. Lawrence (eds.), Focus on Leadership: Servant-leadership for the $27^{\text {st }}$ Century (New York: John Wiley \& Sons, 2002), pp. 53-64.

40 J.S. Lore, 'Servant leadership in a Christian organization: The Sisters of St Joseph Health System', in L.C. Spears (ed.), Insights on Leadership (New York: John Wiley \& Sons, 1998), pp. 297-307.

41 Stephen R. Covey, 'Servant-leadership and Community Leadership in the Twenty-First Century', in L.C. Spears \& M. Lawrence (eds.), Focus on Leadership: Servant-leadership for the $21^{\text {st }}$ Century (New York: John Wiley \& Sons, 2002), pp. 27-34.

42 Danah Zohar, 'Servant-leadership and Rewiring the Corporate Brain', in L.C. Spears \& M. Lawrence (eds.), Focus on Leadership: Servant-leadership for the $21^{\text {st }}$ Century (New York: John Wiley \& Sons, 2002), pp. 111-21. 
In other words, a position alone is not enough for a servant leader - it must be combined with character. That character is built on love-the fruit of the Holy Spirit; a servant leader serves from a base of love. It is a wish to make people happy and to serve future generations, inspired by a vision.

Ruschman says that 'servant leadership is much more than a feel-good concept, it is more than ambition; it is an integrated way of serving all people involved within an organisation. In a way servant leadership is tenacious takes risks'. ${ }^{43}$ The power of the concept of servant leadership according to DeGraaf, 'remains embedded in one's ability to combine the best of being a leader with the best of being a servant. In the end, being a servant leader is not something you do, but rather something you are. To answer a call of servant leadership is a humbling experience. ${ }^{44}$ According to Kim 'it is about a rediscovery of an individual and to connect with the highest aspirations of the organisation'. ${ }^{45}$ At its core, Spears is of the opinion that 'servant leadership is a long term, transformational approach to life and work. In essence, a style of leadership that has the potential for creating positive change throughout society' ${ }^{46}$

The idea of the leader as a servant in the words of Ferch is 'rooted in the farreaching ideal that people have inherent worth. A dignity not only to be strived for, but beneath this striving a dignity irrevocably connected to the reality of

43 N.L. Ruschman, 'Servant-leadership and the Best Companies to Work for in America', in L.C. Spears \& M. Lawrence (eds.), Focus on leadership: Servant-leadership for the $21^{\text {st }}$ century (New York: John Wiley \& Sons, 2002), pp. 123-39.

44 D. DeGraaf, C. Tilley, and C. \& L. Neal, 'Servant-leadership Characteristics in Organizational Life' in L.C, Spears \& M. Lawrence (eds.), Practicing Servant Leadership: Succeeding Through Trust, Bravery, and Forgiveness (San Francisco: Jossey-Bass, 2004), pp. 133-66.

45 D.H. Kim, 'Foresight as the Central Ethic of Leadership', in L.C, Spears \& M. Lawrence (eds.), Practicing Servant Leadership: Succeeding Through Trust, Bravery, and Forgiveness (San Francisco: Jossey-Bass, 2004), pp. 201-24.

46 Lawrance C. Spears, 'The Understanding and Practice of Servant Leadership', in L.C. Spears \& M. Lawrence (eds.), Practising servant-leadership (San Francisco: Jossey-Bass, 2004), pp. 9-24. Personal quest for power, prestige, or material rewards are not priority but serving the followers. Instead, from this perspective, servant leadership begins with a true motivation to serve others. The motivation to serve is not a weakness but it is a fulfilment on the part of the servant leader. Servant leaders are not intimidated by followers because they have a passion to serve them. The focus of servant leadership should be on sharing information, building a common vision, self-management, high levels of interdependence, learning from mistakes, encouraging creative input from every team member, and questioning present assumptions and mental models. A. McGee-Cooper \& D. Trammell, 'From Hero-as-leader to Servant-as-leader', in L.C. Spears \& M. Lawrence (eds.), Focus on Leadership: Servant-leadership for the $21^{\text {st }}$ Century (New York: John Wiley \& Sons, 2002), pp. 141-52. 
being human: ${ }^{47}$ Servant leadership is quite simple, according to Frick 'it is authentic, ethical, trustworthy, exemplary and servile'.48 It is emphasised by Bell that 'servant leaders lead by serving others. In political leadership for example, servant leaders become 'public servants'. ${ }^{49}$ This is the kind of leadership that will be honoured and respected, and the titles that go with a leadership role are earned, not inherited. In addition servant leaders according to Hale and Fields are 'more concerned about followers receiving recognition for their achievements than receiving accolades for their success.' 50

Greatness therefore is not the goal. Elmer asserts that 'service is the goal, and greatness is defined by Christ in His lifelong exercise of service. For the life of Christ to be reproduced in the disciples, it must be through serving others. Leadership and service are immensely compactable.51 Furthermore Ortberg denotes that 'service is not weakness and it is not to make everyone happy. It is not a mindless assent to comprise in order to keep peace. It is not artificial harmony and people pleasing. 52 Augsburger explains that 'service is willing, working, and doing in which a person acts not according to his own purposes or plans, but with a view to the purpose of another person and according to the need, disposition and direction of others..$^{53}$

Servant leader does not avoid leadership. Instead, according to Hutchison 'it is a different kind of leadership, one committed to meeting the needs of others. Similar to the first century slaves, true servant leaders give up their rights for the sake of others. True greatness and true leadership is achieved not by reducing men to one's service, but in giving oneself in selfless service to them. ${ }^{54}$ The true servant leader is concerned infinitely more with the service to God and

47 S.R. Ferch, 'Servant Leadership, Forgiveness, and Social Justice?' in L.C Spears \& M. Lawrence (eds.), Practicing servant-leadership (San Francisco: Jossey-Bass, 2004), pp. 225-40.

48 D.M. Frick, Robert K. Greenleaf: A Life of Servant Leadership (San Francisco: Beret-Koehler, 2004).

49 A. Bell, Great Leadership (California: Davies-Black, 2006).

$5^{\circ}$ J.R. Hale and D.L. Fields, 'Exploring Servant Leadership across Cultures: A Study of Followers in Ghana and the USA'. Leadership 3.4 (2007), pp. 397-417.

$5^{1}$ Duanne H. Elmer, Cross-cultural Servanthood (Downers Grove, IL: IVP books, 2006).

$5^{2}$ N. Ortberg, 'Ministry Implications of Service' in E.O. Jacobsen (ed.) The Three Tasks of Leadership: Worldly Wisdom for Pastoral Leaders (Grand Rapids MI: Eerdmans, 2009), pp. $131-38$.

53 D. Augsburger, 'Evaluating Servant-Hood: From Servant Leadership to Leading as Serving' in E.O. Jacobsen (ed.), The Three Tasks of Leadership: Worldly Wisdom for Pastoral Leaders (Grand Rapids, MI: Eerdmans, 2009), pp. 99-109.

54 Hutchison, 'Servant-hood', p. 69. 
his fellow men than with the benefits and pleasures he can extract from life. Servant leader aims to put more into life than to take out of it.

Tan highlights the fact that 'true servants with a servant's heart make themselves available to serve and pay attention to needs of others. They do their best with what they have and with equal dedication. True servants are faithful to their ministry and maintain a low-profile. ${ }^{55}$ Furthermore, they think more about others than themselves; they think like stewards, not owners, they think about their work, not what others are doing. True servants base their identity in Christ; and they think of ministry as an opportunity, not an obligation.

The servant leader is tough in love and in spirit. Patterson explains that the 'servant leader is willing to walk that extra mile, give, and engage fully in the wellbeing of the organisation and followers. This will sometimes mean having to face the idea of loving the unlovable, and yet, for the servant leader, this concept is a misnomer, in that all people are worthy human beings, deserving of love and respect. ${ }^{56}$ This is much easier to say than to do, and yet the cup of the servant leader is full, full enough to reach for all with this love. The servant leader is willing to love and engage followers in all areas of life.

Servant leaders demand to serve and acquire a position later. They seek to minister first and become great because of the desire to serve others. Take for example 'waiters' in a restaurant; they direct the customers to the table first (e.g., table for two or three), serve the customer and get a 'tip' later. Another good example is that of a petrol attendant who normally asks the motorist what type of fuel they use, performs other duties like changing oil and pouring water into the engine, washes the windscreen and ask for the payment later. This is putting service first and position and money later. This is exactly the style of Jesus leadership. He humbled Himself by serving the people and received benefits later.

\subsection{Servant Leadership is Self-sacrice}

The Son of Man in Mk 10.45 sacrifices with His own life for the remission of sins of many in the world. Servant leadership is self-sacrifice. Choi and Mai-Dalton defines self-sacrifice as the 'total/partial abandonment, and/or permanent/ temporary postponement of personal interests, privileges, or welfare in the

\footnotetext{
55 S. Tan, 'The Primacy of Servant-hood in Jacobsen' in E.O. Jacobsen (ed.) The Three Tasks of Leadership: Worldly Wisdom for Pastoral Leaders (Grand Rapids MI: Eerdmans, 2009), pp. $77^{-90}$.

56 Kathleen Patterson, 'Servant Leadership and Love', in D. Dierendonck \& K. Patternson (eds.), Servant Leadership: Developments in Theory and Research (London: Palgrave Macmillan, 2010), pp. 67-76.
} 
(1) division of labor, (2) distribution of rewards, and (3) exercise of power.'57 According to De Cremer and Van Knippenberg it is 'willingness on the part of the leader to incur personal costs (or run the risk of such costs) to serve the goals and mission of the group or organization' ${ }^{58}$ Self-sacrifice by the leader according to Singh and Krishnah leads to the development of a culture of giving and selfless service in the organization' ${ }^{59}$

Dierendonck states that the 'self-sacrificing behaviour of the leader leads to more charisma, legitimacy, and reciprocity. Followers from leaders who show self-sacrificing behaviour exhibit higher positive emotions and a stronger willingness to work together, are more motivated toward pro-social behaviour and rate their leaders as more effective'. ${ }^{60}$ De Cremer says that 'self-sacrifice lifts up the spirits and hopes of followers through its extraordinary and inspirational nature, which is reflected particularly in the influence it has on followers' emotions and motivation'. ${ }^{61}$

Indeed, being self-sacrificial according to Van Knippenburg and Van Knoppenberg is probably 'one of the most direct ways for leaders to state that they consider the group's welfare to be important, and it also explicitly shows their commitment to the collective'.62 Self-sacrifice communicates the relatively unambiguous message that the leader has a pro-group orientation. Ruggieri and Abbate explain that in self-sacrifice, leaders give up their rewards or refrain from using power for personal benefit'. ${ }^{63}$

Servant leaders as self-sacrificial abandon their own personal interests to pursue the interests of the organisation they are leading. Servant leaders pay

57 Yeon Choi \& R.R. Mai-Dalton, 'The Model of Followers' Responses to Self-Sacrificial Leadership: An Empirical Test', The Leadership Quarterly 10.3 (1999), pp. 397-421.

58 David De Cremer \& D. Van Knippenberg, 'Leader Self-sacrifice and Leadership Effectiveness: The Moderating Role of Leader Self-Confidence', Organizational Behavior and Human Decision Processes 95.2 (2004), pp. 140-55.

59 Niti Singh \& V.R. Krishnah, 'Self-sacrifice and Transformational Leadership: Mediating Role of Altruism', Leadership \& Organization Development Journal 29.3 (2008), pp. 261-74.

6 Dirk Van Dierendonck, 'Servant Leadership: A Review and Synthesis', Journal of management 37.4 (2011), pp. 1228-1261.

61 De Cremer \& Van Knippenberg, 'Leader Self-sacrifice and Leadership Effectiveness', pp. 140-55.

62 B. Van Knippenberg \& D. Van Knippenberg, 'Leader Self-Sacrifice and Leadership Effectiveness: The Moderating Role of Leader Prototypicality', Journal of Applied Psychology 90.1 (2005), pp. 25-39.

63 Stefano Ruggieri and Costanza Scaffidi Abbate, 'Leadership Style, Self-Sacrifice, and Team Identification', Social Behavior and Personality: An International Journal 41.7 (2013), pp. $1171-1178$. 
the price of greatness by risking with their own life. They are follower-oriented as a result the followers are motivated to be under their leadership. They are concerned about the health of the organisation the same way Jesus was concerned about the world.

\section{Conclusion}

Son of Man is the Minister and Life giver in Mk 10.45. The Son of Man as Minister is the one who did not come on earth to be ministered to but to minister to others. Son of Man as Life giver pays a price for the sake of many sinners in the world. The life, crucifixion, death and resurrection of Jesus are the price paid for the release of those who are enslaved by sin. These aspects of Son of Man, that is, Minister and Life giver are aspects of servant leadership.

In one aspect of the Son of man, Minister is linked to the aspect of servant leadership, service. Servant leaders do not seek to be served but serve other people the same way Jesus served the whole world. In another aspect of the Son of Man, Life giver is linked to the aspect of servant leadership, self-sacrifice. Self-sacrifice leaders abandon their own goals to serve the goals of a group or organisation the same way Jesus gave with His own life. In both aspects of the Son of Man, that is, Minister and Life giver in Mk 10.45, servant leadership is studied from a biblical perspective. 